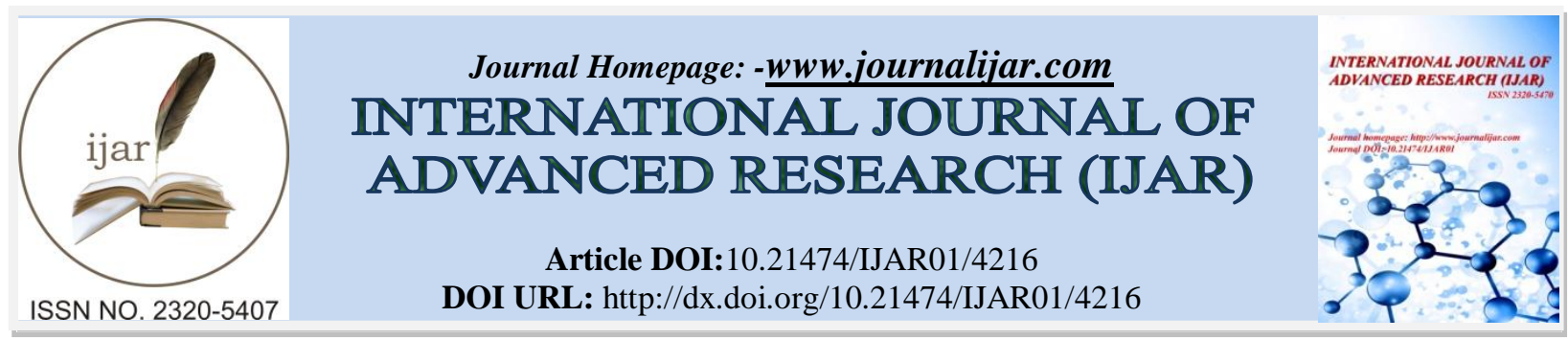

RESEARCH ARTICLE

\title{
METABOLIC FACTORS ASSOCIATED WITH HEPATIC STEATOSIS AND FIBROSIS IN CHRONIC HEPATITIS C PATIENTS.
}

\author{
Ramy M ElSharkawy ${ }^{1}$, GhadaMostafa $\mathbf{K}^{1}$, Mahmoud Saif-Al-Islam AbdElfatah ${ }^{1}$, Eman Mohamed Salah- \\ Eldein $^{2}$, Tamer Elmokadem ${ }^{3}$,Ahmed Hassan ${ }^{3}$ andHydi Ahmed ${ }^{4}$. \\ 1. Departments of Tropical Medicine and Gastroenterology, Faculty of Medicine, SohagUniversity. \\ 2. Pathology, Faculty of Medicine, Sohag University. \\ 3. Microbiology and Immunology, Faculty of Medicine, Sohag University. \\ 4. Clinical Pathology,Faculty of Medicine, Sohag University and Ibn Sina National College, Jeddah,Saudi Arabia.
}

\section{Manuscript Info}

Manuscript History

Received: 17 March 2017

Final Accepted: 20 April 2017

Published: May 2017

Key words:-

CHC, BMI: body mass index, adiponectin, TNF- $\alpha$ : tumor necrotic factor- $\alpha$, HOMA: homeostasis model of assessment.

\section{Abstract}

Objective: Hepatic steatosis is a common histological feature in chronic hepatitis $\mathrm{C}(\mathrm{CHC})$, but its pathogenic mechanisms are not completely understood. We aimed to evaluate the metabolic factors associated with hepatic steatosis and fibrosis in CHC patients, and the relation between metabolic syndrome (MS) and $\mathrm{CHC}$.

Patients and Methods: This study included 71 patients with $\mathrm{CHC}$ infection who underwent clinical, BMI, biochemical (assessment of insulin resistance, serum adiponectin, $\mathrm{TNF}-\alpha$, cholesterol and triglycerides), virological and histological assessments.

Results: Significant steatosis $(>33 \%)$ was detected in $54 \%$ of the patients, while $21.12 \%$ of the patients had stage 3/4 fibrosis. Higher degree of steatosis was significantly associated with higher BMI, serum insulin, HOMA index and TNF- $\alpha(\mathrm{P}<0.0001, \mathrm{P}<0.0006, \mathrm{P}<$ 0.0001 , and $\mathrm{P}<0.01$ respectively). Higher stages of fibrosis were significantly associated with higher BMI and serum triglycerides (P $<0.04$, $\mathrm{P}<0.02$ respectively). Multivariate analysis of the metabolic factors showed that HOMA index $(\mathrm{P}<0.001)$ and TNF- $\alpha(\mathrm{P}<0.03)$ were the factors mostly predicting higher degree of steatosis. While, BMI index $(\mathrm{P}<0.01)$ and serum triglycerides $(\mathrm{P}<0.03)$ were the factors mostly predicting higher stage of fibrosis. We also found that $\mathrm{CHC}$ is closely related to $\mathrm{MS}$, and we recognized that older age $(\mathrm{P}<0.011)$, higher BMI $(\mathrm{p}<0.0001)$, lower serum adiponectin ( $\mathrm{P}$ $<0.0001)$, higher TNF- $\alpha(\mathrm{p}<0.0001)$ and higher steatosis degree $(\mathrm{p}<0.04)$ were significantly associated with MS in these patients.

Conclusions: In patients with CHC, higher BMI, HOMA-IR, serum TNF- $\alpha$ and triglycerides and lower serum adiponectin were associated with HCV hepatic steatosis and metabolic syndrome, while higher BMI and serum triglycerides were associated with more advanced fibrosis stage.

Copy Right, IJAR, 2016,. All rights reserved. 


\section{Introduction:-}

Hepatitis $\mathrm{C}$ virus (HCV) infection is an important public health problem because approximately 170 million people are infected worldwide. Chronic liver disease results from persistent infection in the majority of patients infected with the virus ${ }^{(1)}$. The Egyptian Demographic Health Survey (EDHS), a cross sectional survey including hepatitis C virus (HCV) biomarkers, was conducted in 2008 on a large nationally representative sample ${ }^{(2)}$. It estimated HCV prevalence among the $15-59$ years age group to be $14.7 \%$. Accordingly, Egypt has the highest HCV prevalence in the world ${ }^{(3)}$. Liver steatosis is a common finding in patients infected with hepatitis $\mathrm{C}$ virus (HCV) ${ }^{(4)}$. HCV steatosis was recently identified as a risk factor for progression to extensive fibrosis ${ }^{(5)}$. Chronic HCV infection is closely related to the metabolic syndrome (MS). Accordingly, CHC should be classified into $\mathrm{CHC}$ with and $\mathrm{CHC}$ without MS. Insulin resistance (IR) is the main feature of the MS. In CHC, there is a close association between IR, hepatic steatosis $^{(6)}$, and progression of fibrosis ${ }^{(7)}$.

The adipocytokine profile seems to play a distinct role, together with IR, in the pathogenesis of CHC ${ }^{(8)}$. Adiponectin modulates hepatic fat content and has an anti-steatotic effect on the liver ${ }^{(9)}$. Adiponectin is also a hepatic insulin sensitizer and has the opposite effect in comparison with tumor necrotic factor (TNF- $\alpha$ ) on lipid metabolism, insulin sensitivity and inflammation ${ }^{(10)}$. In CHC, adiponectin levels are also associated with the degree of steatosis and insulin resistance ${ }^{(11)}$. Abnormalities of lipid metabolism such as the increase of serum triglyceride, cholesterol and LDL-cholesterol level and decrease in HDL-cholesterol may be the contributing factors in the development of $\mathrm{NASH}^{(12)}$.

\section{Aim of the work:-}

We aimed to evaluate metabolic factors associated with hepatic steatosis and fibrosis in patients infected with CHC, and to assess the impact of insulin resistance (as measured by HOMA-IR score) and serum adipocytokines levels on hepatic steatosis and fibrosis relative to other factors. Finally, to evaluate the relationship between $\mathrm{CHC}$ and metabolic syndrome.

\section{Patients and Methods:-}

The present study included 71 patients (49 males and 22 females) with chronic hepatitis C (CHC). Their ages ranged from 21-57 years. All patients were referred to the Department of Tropical Medicine and Gastroenterology, Sohag University Hospital and to Sohag Specialized Liver Institute (in the period from August 2011 to Septemper 2013) for doing liver biopsies and the complementary laboratory tests before starting treatment with pegylated interferon and ribavirin therapy at Sohag Specialized Liver Institute. Before inclusion in the study, all participants gave informed consents and the study protocol was approved by the Local Ethics Committee.

In addition, 12 age and sex matched healthy individuals were also included to serve as a control group.

Patients were diagnosed as chronic hepatitis $\mathrm{C}$ based on clinical data, positive anti-HCV by ELISA test and HCV RNA by PCR for more than 6 months.

\section{Exclusion Criteria:-}

Patients were excluded if they have any of the following:

$>$ Hepatitis B virus co-infection,

$>$ Autoimmune disease.

$>$ Alcohol consumption.

$>$ Decompensated liver disease.

$>$ Pregnancy or breast feeding.

Patient with other medical disease as renal or ischaemic heart disease, significant retinal abnormality, uncontrolled neuropsychiatric disease, immunologically mediated disease, or organ transplantation

\section{Methods:-}

The following were done to all patients:

Complete history taking and full clinical examination.

Body mass index was calculated from patients' weight: patients' weight $(\mathrm{Kg}) /$ patients' height (meter) ${ }^{2}$. 


\section{Investigations:-}

Laboratory:-

a. Liver function tests: serum albumin, ALT, AST, total bilirubin, direct \& indirect bilirubin, prothrombin time and concentration by standard methods.

b. Fasting serum glucose, creatinine, and complete blood picture.

c. Polymerase chain reaction (PCR) for HCV.

d. Serum cholesterol and triglycerides.

e. Measurement of serum adiponectin and serum TNF- $\alpha$.

f. Fasting serum insulin to calculate HOMA index.

\section{Abdominal ultrasonography:-}

Histopathological assessment:-

Seventy one liver biopsies were included in the study and submitted to histopathological examination. Hematoxylin and eosin (H\&E) stained sections were done to assess both the grade and the stage of chronic viral hepatitis, in addition to the degree of steatosis. Metavir grading and staging systems were used.

\section{Statistical Analysis:-}

Data were computed and analyzed using STATA intercooled version 9.2. Quantitative data were analyzed using ANOVA test and Post Hoc Bonferroni test for comparison of the means of three groups. When the data were not normally distributed Kruskal -Wallis rank test and Mann-Whitney test were used. Qualitative data were compared using Chi square test. $\mathrm{P}$ value was considered significant if it was less than 0.05 . Both univariate and multivariate analyses were used to determine risk factors (predictors) of significant steatosis (moderate and severe), and the risk factors (predictors) of advanced fibrosis (stage 3 and 4).

\section{Results:-}

This study was conducted on 71 patients with chronic hepatitis $\mathrm{C}$ who fulfilled the study's inclusion criteria. The patients were predominantly males (49 males and 22 females), with ages ranging from $20-57$ years and a mean age of $41.86 \pm 9.70$. Besides, 12 persons served as controls ( 7 males and 5 females), with ages ranging from $22-50$ years and a mean age of $41.75 \pm 7.66$. According to the histopathology reports, the studied patients were classified according to the degree of steatosis into 2 groups: Steatosis group 1: includes 33 patients $(46.5 \%)$ with chronic hepatitis $\mathrm{C}$ and steatosis $<33 \%$. Steatosis group 2: includes 38 patients $(53.5 \%)$ with chronic hepatitis $\mathrm{C}$ and steatosis> $33 \%$.

The same patients were also categorized according to the fibrosis score into 3 groups: Fibrosis group 1: includes 40 patients (56.3\%) with fibrosis score F 0/1. Fibrosis group 2: includes 16 patients (22.5\%) with fibrosis score F2. Fibrosis group 3: includes 15 patients $(21.1 \%)$ with fibrosis score $\mathrm{F} 3 / 4$.

Table 1:- Comparison between each steatosis group and controls.

\begin{tabular}{|c|c|c|c|c|c|c|}
\hline Characteristic & $\begin{array}{c}\text { Steatosis } \\
\text { group1 } \\
\mathrm{N}=33\end{array}$ & $\begin{array}{c}\text { Steatosis } \\
\text { group } 2 \\
\mathrm{~N}=38\end{array}$ & $\begin{array}{c}\text { Controls } \\
\mathrm{N}=12\end{array}$ & $\begin{array}{c}\text { Steatosis } \\
\text { group } 1 \\
\text { versus } \\
\text { group } 2\end{array}$ & $\begin{array}{c}\text { Steatosis } \\
\text { group } 1 \\
\text { versus } \\
\text { controls }\end{array}$ & $\begin{array}{c}\text { Steatosis } \\
\text { group } 2 \\
\text { versus } \\
\text { controls }\end{array}$ \\
\hline $\begin{array}{l}\text { Age } \\
\text { Mean } \pm \text { SD }\end{array}$ & $39.88 \pm 10.35$ & $43.62 \pm 8.85$ & $\begin{array}{l}41.75 \\
\pm 7.66 \\
\end{array}$ & 0.11 & 0.52 & 0.09 \\
\hline $\begin{array}{l}\text { Gender }(\mathbf{n}, \%) \\
\text { Males } \\
\text { Females }\end{array}$ & $\begin{array}{c}25(75.76 \%) \\
8(24.24 \%)\end{array}$ & $\begin{array}{l}24(64.86 \%) \\
13(35.14 \%)\end{array}$ & $\begin{array}{l}7(58.3 \%) \\
5(41.7 \%)\end{array}$ & 0.32 & 0.09 & 0.36 \\
\hline $\begin{array}{ll}\text { DM } & \\
\text { No } & (n=47) \\
\text { Yes } & (n=24) \\
\end{array}$ & $\begin{array}{c}27(81.81 \%) \\
6(18.19 \%)\end{array}$ & $\begin{array}{l}20(52.6 \%) \\
18(47.4 \%)\end{array}$ & & 0.17 & & \\
\hline $\begin{array}{l}\text { Body mass index } \\
\text { (BMI) } \\
\text { Mean } \pm \text { SD }\end{array}$ & $25.60 \pm 3.42$ & $29.2 \pm 3.57$ & $\begin{array}{l}24.33 \\
\pm 1.82 \\
\end{array}$ & 0.0001 & 0.23 & 0.0001 \\
\hline $\begin{array}{l}\text { ALT (IU/L) } \\
\text { Mean } \pm \text { SD }\end{array}$ & $62.45 \pm 41.49$ & $72.89 \pm 79.01$ & $32.58 \pm 5.14$ & 0.83 & 0.001 & 0.0002 \\
\hline
\end{tabular}




\begin{tabular}{|c|c|c|c|c|c|c|}
\hline $\begin{array}{l}\text { AST (IU/L) } \\
\text { Mean } \pm \text { SD }\end{array}$ & $47.45 \pm 22.03$ & $63.89 \pm 67.06$ & $\begin{array}{l}29.17 \\
\pm 5.89\end{array}$ & 0.24 & 0.004 & 0.0001 \\
\hline $\begin{array}{l}\text { Triglyceride } \\
(\mathrm{mg} / \mathrm{dl}) \\
\text { Mean } \pm \text { SD }\end{array}$ & $\begin{array}{l}115.06 \\
\pm 30.82 \\
\end{array}$ & $\begin{array}{r}139.86 \\
\pm 34.72 \\
\end{array}$ & $\begin{array}{r}96.25 \\
\pm 11.69 \\
\end{array}$ & 0.003 & 0.046 & 0.0001 \\
\hline $\begin{array}{l}\text { Cholesterol (mg/ } \\
\text { dl) } \\
\text { Mean } \pm \text { SD }\end{array}$ & $\begin{array}{l}142.55 \\
\pm 29.85 \\
\end{array}$ & $\begin{array}{r}153.68 \\
\pm 39.78\end{array}$ & $130 \pm 21.85$ & 0.19 & 0.19 & 0.06 \\
\hline $\begin{array}{l}\text { Adiponectin } \\
\text { (ng/ml) } \\
\text { Mean } \pm \text { SD }\end{array}$ & $26.45 \pm 4.50$ & $20.49 \pm 5.01$ & $\begin{array}{l}28.45 \\
\pm 4.03\end{array}$ & 0.0001 & 0.19 & 0.0001 \\
\hline $\begin{array}{l}\text { TNF- } \alpha(\mathrm{pg} / \mathrm{ml}) \\
\text { Mean } \pm \text { SD }\end{array}$ & $\begin{array}{l}100.29 \\
\pm 41.25\end{array}$ & $\begin{array}{l}128.01 \\
\pm 47.21\end{array}$ & $\begin{array}{l}49.47 \\
\pm 9.58\end{array}$ & 0.01 & 0.0001 & 0.0001 \\
\hline $\begin{array}{l}\text { Insulin }(\mu \mathrm{U} / \mathrm{ml}) \\
\text { Mean } \pm \text { SD }\end{array}$ & $1.83 \pm 1.51$ & $3.44 \pm 2.11$ & $1.84 \pm 1.86$ & 0.0006 & 0.99 & 0.02 \\
\hline $\begin{array}{l}\text { HOMA } \\
\text { Mean } \pm \text { SD }\end{array}$ & $1.67 \pm 0.66$ & $3.44 \pm 0.77$ & $1.42 \pm 0.40$ & 0.0001 & 0.32 & 0.0001 \\
\hline $\begin{array}{l}\text { Viral load } \\
\text { Mean } \pm \text { SD }\end{array}$ & $\begin{array}{r}760591.5 \\
\pm 1205421 \\
\end{array}$ & $\begin{array}{c}523987.7 \\
\pm 992435.9\end{array}$ & & 0.71 & & \\
\hline
\end{tabular}

$\mathrm{N}=$ number

When steatosis groups were compared regarding their laboratory data, we found that BMI, serum insulin and HOMA index were significantly higher in steatosis group 2 than group $1(\mathrm{P}=0.0001, \mathrm{P}=0.0006$ and $\mathrm{P}=0.0001$, respectively). Serum adiponectin was significantly higher in steatosis group $1(\mathrm{P}=0.0001)$, while serum TNF- $\alpha$ was higher in steatosis group $2(\mathrm{P}=0.01)$. Serum lipogram shows significantly higher triglycerides in steatosis group 2 $(\mathrm{P}=0.003)$. While no significant difference was found between the two groups as regards age, gender, ALT, AST, serum cholesterol and viral load. Patients in steatosis group 1 have significantly higher serum ALT and AST levels $(\mathrm{P}=0.001, \mathrm{P}=0.004$ respectively), TNF- $\alpha(\mathrm{P}=0.0001)$, and serum triglycerides $(\mathrm{P}=0.046)$, compared to the controls. Patients in steatosis group 2 have higher BMI $(\mathrm{P}=0.0001)$, ALT, AST levels $(\mathrm{P}=0.0002, \mathrm{P}=0.0001$ respectively), serum triglycerides, serum TNF- $\alpha$, HOMA index, $(\mathrm{P}=0.0001$ for each), and higher serum insulin $(\mathrm{P}=$ 0.02 ) compared to the controls. On the other hand, serum adiponectin was significantly lower in steatosis group 2 than the controls $(\mathrm{P}=0.0001)$ (Table 1).

Table 2:- Laboratory and clinical results of studied groups within each stage of fibrosis

\begin{tabular}{|c|c|c|c|c|c|c|c|}
\hline Characteristic & $\begin{array}{l}\text { Stage 0/1 } \\
\mathrm{N}=40\end{array}$ & $\begin{array}{l}\text { Stage } 2 \\
N=15\end{array}$ & $\begin{array}{l}\text { Stage } \\
\mathrm{N}=15\end{array}$ & $\begin{array}{l}\text { Comparosin } \\
\text { between } \\
\text { different stages } \\
\text { of fibrosis }\end{array}$ & $\begin{array}{l}\text { Stage } \\
0 / 1 \\
\text { versus } \\
\text { stage } 2 \\
\end{array}$ & $\begin{array}{l}\text { Stage } 0 / 1 \\
\text { versus } \\
\text { stage } 3 / 4\end{array}$ & $\begin{array}{l}\text { stage } 2 \\
\text { versus } \\
\text { stage } 3 / 4\end{array}$ \\
\hline $\begin{array}{l}\text { Age } \\
\text { Mean } \pm \text { SD }\end{array}$ & $\begin{array}{c}39.72 \\
\pm 10.09\end{array}$ & $43.2 \pm 8.18$ & $46.2 \pm 8.84$ & 0.07 & 0.69 & 0.08 & 1.00 \\
\hline $\begin{array}{l}\text { Body mass } \\
\text { index }(\mathrm{BMI}) \\
\text { Mean } \pm \text { SD }\end{array}$ & $\begin{array}{l}25.02 \\
\pm 3.45 \\
\end{array}$ & $\begin{array}{l}25.69 \\
\pm 3.20 \\
\end{array}$ & $29.07 \pm 3.93$ & 0.04 & 1.00 & 0.01 & 0.01 \\
\hline $\begin{array}{l}\text { ALT (IU/L) } \\
\text { Mean } \pm \text { SD }\end{array}$ & $\begin{array}{c}56.05 \\
\pm 31.27 \\
\end{array}$ & $\begin{array}{c}66.4 \\
\pm 42.39 \\
\end{array}$ & $101.33 \pm 118.33$ & 0.27 & 0.26 & 0.16 & 0.68 \\
\hline $\begin{array}{l}\text { AST (IU/L) } \\
\text { Mean } \pm \text { SD }\end{array}$ & $\begin{array}{c}46.73 \\
\pm 18.82 \\
\end{array}$ & $\begin{array}{c}49.4 \\
\pm 19.56 \\
\end{array}$ & $88 \pm 101.25$ & 0.19 & 0.56 & 0.07 & 0.31 \\
\hline $\begin{array}{l}\text { Triglyceride } \\
(\mathrm{mg} / \mathrm{dl})\end{array}$ & & & & & & & \\
\hline
\end{tabular}




\begin{tabular}{|c|c|c|c|c|c|c|c|}
\hline Mean \pm SD & $\begin{array}{l}119.08 \\
\pm 32.14\end{array}$ & $\begin{array}{l}133.87 \\
\pm 35.25\end{array}$ & $146.73 \pm 35.74$ & 0.02 & 0.45 & 0.03 & 0.89 \\
\hline $\begin{array}{l}\text { Cholesterol } \\
(\text { mg/dl) } \\
\text { Mean } \pm \text { SD }\end{array}$ & $\begin{array}{l}147.38 \\
\pm 34.59 \\
\end{array}$ & $\begin{array}{l}163.67 \\
\pm 40.21\end{array}$ & $136 \pm 29.89$ & 0.09 & 0.39 & 0.86 & 0.10 \\
\hline $\begin{array}{l}\text { Adiponectin } \\
\text { (ng/dl) } \\
\text { Mean } \pm \text { SD }\end{array}$ & $\begin{array}{l}23.19 \\
\pm 4.45 \\
\end{array}$ & $\begin{array}{r}23.25 \\
\pm 5.52 \\
\end{array}$ & $24.19 \pm 5.38$ & 0.79 & 1.00 & 1.00 & 1.00 \\
\hline $\begin{array}{l}\text { TNF- } \alpha(\mathrm{pg} / \mathrm{dl}) \\
\text { Mean } \pm \text { SD }\end{array}$ & $\begin{array}{l}106.21 \\
\pm 44.09\end{array}$ & $\begin{array}{r}117.89 \\
\pm 54.85\end{array}$ & $135.27 \pm 38.51$ & 0.11 & 1.00 & 0.12 & 0.90 \\
\hline $\begin{array}{l}\text { HOMA } \\
\text { Mean } \pm \text { SD }\end{array}$ & $2.49 \pm 1.14$ & $3.03 \pm 1.23$ & $2.50 \pm 1.04$ & 0.31 & 0.14 & 1.00 & 0.24 \\
\hline $\begin{array}{l}\text { Viral load } \\
\text { (copies/ml) } \\
\text { Mean } \pm \text { SD }\end{array}$ & $\begin{array}{r}679725.9 \\
\pm 1325751 \\
\end{array}$ & $\begin{array}{c}478240.5 \\
\pm 724249.2 \\
\end{array}$ & $\begin{array}{c}674961.4 \\
\pm 684944.6\end{array}$ & 0.44 & 0.56 & 0.30 & 0.27 \\
\hline
\end{tabular}

The clinical characteristics of studied population within each stage of fibrosis were shown in Table 2. We did not find any significant difference between the 3 groups of the studied population as regards serum ALT, AST, adiponectin, TNF- $\alpha$ and HOMA index. While a significant difference was found in BMI, and serum triglycerides being highest in stage $3 / 4$ fibrosis $(\mathrm{P}=0.04, \mathrm{P}=0.02$ respectively).

Table 3:- Multivariate analysis for the factors predicting higher degree of steatosis

\begin{tabular}{|l|c|c|}
\hline Variables & Odds ratio (95\% Confidence Interval) & P value \\
\hline TNF- $\alpha$ & $\mathbf{0 . 9 7}(\mathbf{0 . 9 4 - 0 . 0 . 9 9 )}$ & $\mathbf{0 . 0 3}$ \\
\hline HOMA index & $\mathbf{0 . 0 0 4}(\mathbf{0 . 0 0 - 0 . 1 3 )}$ & $\mathbf{0 . 0 0 1}$ \\
\hline
\end{tabular}

Table 4:-Multivariate analysis for the factors predicting higher stage of fibrosis

\begin{tabular}{|c|c|c|}
\hline Variables & Odds ratio (95\% Confidence Interval) & P value \\
\hline BMI & $\mathbf{0 . 9 1}(\mathbf{0 . 8 3 - 0 . 9 9 )}$ & $\mathbf{0 . 0 1}$ \\
\hline Triglycerides & $\mathbf{3 2 . 0 4}(\mathbf{1 . 4 5 - 7 0 6 . 0 2})$ & $\mathbf{0 . 0 3}$ \\
\hline
\end{tabular}

Multivariate analysis of the factors mostly predicting higher degree of steatosis, showed that TNF- $\alpha(\mathrm{P}=0.03)$ and HOMA index $(\mathrm{P}=0.001)$ are the factors mostly predicting higher degree of steatosis(Table 3$)$. Multivariate analysis of the factors mostly predicting higher degree of fibrosis showed that $\mathrm{BMI}$ index $(\mathrm{P}=0.01)$ and serum triglycerides $(P=0.03)$ are the factors mostly predicting higher stage of fibrosis (Table 4).

Table 5:- Characteristics of CHC patients according to the presence or absence of metabolic syndrome

\begin{tabular}{|c|c|c|c|}
\hline \multirow[t]{2}{*}{ Variables } & \multicolumn{3}{|c|}{ Metabolic syndrome } \\
\hline & absent & present & $\mathbf{P}$ \\
\hline Number & 46 & 25 & \\
\hline Age & $46.08 \pm 4.32$ & $48.68 \pm 3.84$ & 0.011 \\
\hline $\begin{array}{l}\text { Gender } \\
\quad \text { Males: (n, \%) } \\
\text { Females: }(\mathbf{n}, \%)\end{array}$ & $\begin{array}{l}32(65 \%) \\
14(64 \%)\end{array}$ & $\begin{array}{l}17(35 \%) \\
8(36 \%)\end{array}$ & 0.89 \\
\hline BMI & $24.24 \pm 1.74$ & $28.8 \pm 3.5$ & 0.0001 \\
\hline Blood pressure $>130 / 85 \mathrm{mmHg}(\mathrm{n}, \%)$ & $22(47.8)$ & $21(84)$ & 0.003 \\
\hline ALT (IU/L) & $57.56 \pm 44.23$ & $74.41 \pm 76.22$ & 0.21 \\
\hline AST (IU/L) & $46.33 \pm 26.01$ & $62.45 \pm 64.38$ & 0.14 \\
\hline Serum triglycerides $(<150 \mathrm{mg} / \mathrm{dl})$ & $118.25 \pm 78$ & $178.85 \pm 45$ & 0.003 \\
\hline Total serum cholesterol (mg/dl) & $132 \pm 26.18$ & $157 \pm 32.33$ & 0.0007 \\
\hline $\begin{array}{l}\text { HDL-cholersterol (mg/dl) } \\
<40(\mathrm{M}) \\
<50(\mathrm{~F})\end{array}$ & $\begin{array}{l}41.2 \pm 2.1 \\
52.34 \pm 6.23\end{array}$ & $\begin{array}{l}38.5 \pm 2.45 \\
50.58 \pm 5.66\end{array}$ & $\begin{array}{l}\mathbf{0 . 0 0 2} \\
0.2326 \\
\end{array}$ \\
\hline Adiponectin (ng/dl) & $27.33 \pm 4.7$ & $21.02 \pm 3.7$ & 0.0001 \\
\hline
\end{tabular}




\begin{tabular}{|c|c|c|c|}
\hline TNF- $\alpha$ (pg/dl) & $98.54 \pm 31.29$ & $130.05 \pm 39.65$ & 0.0001 \\
\hline Fasting glucose (mg/dl) & $99.04 \pm 2.41$ & $116.23 \pm 3.65$ & 0.0001 \\
\hline Fasting insulin $(\mu \mathrm{U} / \mathrm{ml})$ & $1.78 \pm 1.4$ & $3.18 \pm 2.2$ & 0.002 \\
\hline HOMA-IR & $1.4 \pm 0.54$ & $3.66 \pm 0.78$ & 0.0001 \\
\hline $\begin{array}{l}\text { Steatosis degree: }(\mathrm{n}, \%) \\
\text { Group1: } \\
\text { Group2: }\end{array}$ & $\begin{array}{l}26 / 33(78.9 \%) \\
20 / 38(52.63 \%)\end{array}$ & $\begin{array}{l}7 / 33(21.2 \%) \\
18 / 38(47.4)\end{array}$ & 0.04 \\
\hline $\begin{array}{ll}\text { Fibrosis: }(n, \%) \\
\text { F 0/1: } \quad(n=40) \\
\text { F 2: } \quad(n=16) \\
\text { F 3/4: } \quad(n=15) \\
\end{array}$ & $\begin{array}{l}30(75 \%) \\
10(63 \%) \\
11(73 \%)\end{array}$ & $\begin{array}{l}10(25 \%) \\
6(37 \%) \\
4(27 \%) \\
\end{array}$ & 0.64 \\
\hline
\end{tabular}

To assess whether hepatic steatosis in the current series is related to the presence of metabolic syndrome, patients were re-categorized into a group without MS $(n=46)$ and a group with MS $(n=25)$. We found 12 variables; patients with older age, higher BMI, elevated blood pressure more than $130 / 85 \mathrm{mmHg}$, higher serum triglycerides, total serum cholesterol, HDL- cholesterol in males, serum TNF- $\alpha$, fasting blood glucose, fasting serum insulin, HOMAIR, steatosis degree and lower serum adiponectinweresignificantly related to the MS (Table 5).

\section{Discussion:-}

Chronic hepatitis $\mathrm{C}$ has many features which suggest that this disease must be viewed not only as a viral disease, but also as a metabolic liver disease which implies insulin resistance ${ }^{(13)}$, and high prevalence of steatosis ${ }^{(14)}$.Hourigan et $\mathbf{a l}^{(15)}$ found a significant relationship between hepatic fibrosis and steatosis, suggesting that in chronic $\mathrm{HCV}$ infection steatosis may play a role in disease progression.

Our results showed that significant hepatic steatosis (affecting $>33 \%$ of cells) was present in $53.5 \%$ of studied CHC patients. Hepatic steatosis in our study was significantly higher than that reported in Greek patients with CHC genotype 4 where $26.4 \%$ of them showed significant steatosis ${ }^{(16)}$.

In the current study, patients with different severity of steatosis did not show significant difference in their mean age. This was in agreement with El-Zayadi et al ${ }^{(17)}$ who demonstrated that age is not significantly correlated with steatosis among HCV genotype 4 infected patients. In our study, we found no relation between hepatic fibrosis and age, unlike Hu et al ${ }^{(18)}$ who declared that older patients had advanced stages of fibrosis.

Our study showed a significant association between BMI and the severity of steatosis. This agrees with $\mathbf{H u}$ et al ${ }^{(18)}$ and Negro and Sanyal ${ }^{(19)}$ who found that BMI plays an important role in steatosis in patients with HCV, and disagrees with Adinolfi et $\mathbf{a l}^{(8)}$ who found that steatosis was not significantly associated with BMI in the overall cohort study of $\mathrm{HCV}$ infected patients.

In our study, we found a significant relation between BMI and stages of fibrosis. And this agrees with Hourigan et $\mathbf{a l}^{(15)}$ and $\mathbf{H u}$ et $\mathbf{a l}^{(18)}$.

We found that type $2 \mathrm{DM}$ was present more in steatosis group $2(47.4 \%)$ than in steatosis group 1 (18.19\%), but with no statistically significant difference. El-Zayadi et $\mathbf{a l}^{(17)}$ also declared that DM was not significantly associated with hepatic steatosis in HCV genotype 4 patients. We as well as others, Castera et al ${ }^{(19)}$ and Negro and Sanyal ${ }^{(20)}$ also found a significant association between levels of serum triglycerides and the degree of steatosis in patients with CHC. This disagrees with $\mathbf{H u}$ et $\mathbf{a l}^{(21)}$ who revealed in their cohort of patients with chronic hepatitis $\mathrm{C}$, that hypertriglyceridemia was not significantly associated with hepatic steatosis.

In our study, we found a significant relationship between the serum triglycerides and fibrosis stage. This was in agreement with Hu et $\mathbf{a l}^{(18)}$ and in contrast to Solis-Herruzo et $\mathbf{a l}^{(22)}$ who failed to confirm this relation.

In the current study, mean serum adiponectin level was significantly lower in patients than controls. Also, it was significantly lower in steatosis group 2 than steatosis group 1 . On the other hand, CHC patients showed significantly higher TNF- $\alpha$ level than the control. Also, TNF- $\alpha$ was significantly more raised in steatosis group 2 than 
steatosisgroup 1. The same result was also reported by Durante-Mangoni et al ${ }^{(23)}$ who found that low level of adiponectin and elevated level of TNF- $\alpha$ were independently associated with grades of steatosis and HOMA-IR.

The elevated level of TNF- $\alpha$ had a direct relationship to the progression of fibrosis in CHC patients ${ }^{(24)}$. Lu et al ${ }^{(25)}$ found that serum level of adiponectin did not differ significantly between healthy subjects and patients with $\mathrm{HCV}$ infection.

In the current study, higher serum insulin level was found in more advanced steatosis than in milder group and controls. Also, we found that insulin resistance (IR) measured by HOMA-IR was significantly higher in CHC patients than control, and it was significantly higher in steatosis group 2 than in steatosis group 1. This was in agreement with Cua et $\mathbf{a l}^{(11)}$ and Lawrence and Jacqueline ${ }^{(26)}$ who demonstrated that patients with HCV have more insulin resistance than those without. This also agrees with Younossi et $\mathbf{a l}^{(27)}$ who demonstrated that patients with HCV have more insulin resistance and poor response to treatment. In contrast to our study, Muzzi et al ${ }^{(28)}$ delineated in their cohort study that the level of insulin resistance was not correlated with hepatic steatosis in HCV infected patients.

In the present study, no correlation was found between insulin resistance as measured by HOMA-IR and hepatic fibrosis in CHC patients, and this conforms with Grigorscu et $\mathbf{a l}^{(29)}$ who revealed a lack of correlation between IR and fibrosis. In contrast to D'Souza et $\mathbf{a l}^{(30)}$ who reported that IR plays an important role in hepatic fibrosis in CHC patients, irrespective of the genotype.

Multivariate analysis of our data revealed that TNF- $\alpha(\mathrm{P}=0.03)$ and HOMA index $(\mathrm{P}=0.001)$ are the most independent factors predicting hepatic steatosis in patients with CHC. Steatosis was not an independent factor associated with fibrosis, and only BMI $(\mathrm{P}=0.01)$ and triglycerides $(\mathrm{P}=0.03)$ were independently predict advanced fibrosis.

Our findings disagrees with Rubbia-Brandt et $\mathbf{a l}^{(31)}$ and Cholet et $\mathbf{a l}^{(4)}$ who reported a significant association between steatosis and high stage of fibrosis.

Our results showed that steatosis was significantly associated with the presence of MS in CHC patients. This was also reported by Grigorscu et $\mathbf{a l}^{(29)}$ in patients with HCV genotype 1.

This together with the absence of a significant association between viral load and degree of steatosis in our study strongly suggest that steatosis in the current series is due to metabolic origin.

\section{Conclusion:-}

In patients with CHC, higher BMI, HOMA-IR, higher serum TNF- $\alpha$, triglycerides and lower serum adiponectin were associated with HCV hepatic steatosis and metabolic syndrome, while higher BMI and serum triglycerides were associated with more advanced fibrosis stage.

\section{References:-}

1. Snyder N, Nguyen A, Gajula L, Soloway R, Xiao SY, Lau DT, Petersen J. The APRI may be enhanced by the use of FIBROSpect II in the estimation of fibrosis in chronic hepatitis C. ClinChimActa 2007; 381(2):119-23.

2. El-Zanaty F and Way A. Egypt Demographic and Health Survey 2008. Egyptian Ministry of Health. Cairo: El-Zanaty and Associates, and Macro International; 2009.

3. Lavanchy D. Evolving epidemiology of hepatitis C virus. ClinMicrobiol Infect2011; 17(2):107-15.

4. Gordon A, James M, McLean CA, Bailey MJ, Roberts SK. Steatosis in chronic hepatitis B and C: Predictors, distribution and effect on fibrosis. Hepatology 2005; 43(1):38-44.

5. Cholet F, Nousbaum JB, Richecour M, Emmanuel O, Cauvin J, Lagarde $\mathrm{N}$ et al. Factors associated with liver steatosis and fibrosis in chronic hepatits C patients. GastroenterolClinBiol 2004; 28(3):272-8.

6. Camma C, Bruno S, Di Marco V, Di Bona D, Rumi M, Vinci M et al. Insulin resistance is associated with steatosis in nondiabetic patients with genotype 1 chronic hepatitis C. Hepatology2006; 43(1):64-71.

7. Hui JM, Sud A, Farrell GC, Bandara P, Byth K, Kench JG et al. Insulin resistance is associated with chronic hepatitis $\mathrm{C}$ virus infection and fibrosis progression [corrected]. Gastroenterology 2003; 125(6):1695-704. 
8. Adinolfi LE, Gambardella M, Andreana A, Tripodi MF, Utili R, Ruggiero G. Steatosis accelerates the progression of liver damage of chronic hepatitis $\mathrm{C}$ patients and correlates with specific HCV genotype and visceral obesity. Hepatology 2001; 33(6):1358-64.

9. Tsochatzis E, Papatheodoridis GV and Archimandritis AJ. The Evolving Role of Leptin and Adiponectin in Chronic Liver diseases. Am J Gastroenterol 2006; 101(11): 2629-40.

10. Diehl AM, Li ZP, Lin HZ, Yang SQ. Cytokines and the pathogenesis of non-alcoholic steatohepatitis. Gut 2005; 54(2): 303-6.

11. Cua IA, Jason M. Hui, PriyankaBandara, James G. Kench, et al. Insulin resistance and liver injury in hepatitis $\mathrm{C}$ is not associated with virus-specific changes in adipocytokines. Hepatology 2007; 46(1):66-73,

12. Koruk M, Savas MC, Yilmaz O, Tayşi S, Karakok M, Gündoğdu C et al. Serum lipids, lipoproteins and apolipoproteins levels in patients with non alcoholicsteatohepatitis. Clin Gastroenterol2003; 37(2): 177-82.

13. Fartoux L, Chazouilleres O, Wendum D , Poupon R, Serfaty L. Impact of steatosis on progression of fibrosis in patients with mild hepatitisC. Hepatology 2005; 41(1):82-7.

14. Adinolfi LE, Durante-Mangoni E, Zampino R, Ruggiero G. Review article: hepatitis C virus-associated steatosis pathogenic mechanisms and clinical implications. Aliment PharmacolTher 2005; 22 (suppl 2): 52-5.

15. Hourigan F, Graeme A, David P, Vicki H. Whitehall, Claudia Shorthouse, Andrew Clouston et al. Fibrosis in chronic hepatitis C correlates significantly with body mass index and steatosis. Hepatology 1999; 29(4):1215-1219.

16. Savvas SP, Koskinas J, Sinani C, Hadziyannis A, Spanou F, Hadziyannis SJ. Changes in epidemiological patterns of HCV infection and their impact on liver disease over the last 20 years in Greece. J Viral Hepat 2005; 12(5):551-7.

17. El-Zayadi A, Barakat E, Hamdy H. Hepatic steatosis among HCV genotype 4 patients and its impact on response to interferon therapy. Abstracts of the Biennial Meeting of the International Association of the Study of the Liver (IASL) in Cairo. Official Journal of IASL 2006; 26(Suppl 1). Abstract 213

18. Hu SX, Kyulo NL, Xia VW, Hillebrand DJ, Hu KQ. Factors associated with hepatic fibrosis in patients with chronic hepatitis C: a retrospective study of a large cohort of U.S patients. J ClinGastroenterol 2009; 43(8):758-64.

19. Castera L, Hezode C, Roudot F. Worsening of steatosis is an independent factor of fibrosis progression in untreated patients with chronic hepatitis C and paired liver biopsies. Gut 2003; 52(2):288-92.

20. Negro F, Sanyal AJ. Hepatitis C virus, steatosis and lipid abnormalities: clinical and pathogenic data. Liver Int 2009; 29 (Suppl 2) 26-37.

21. Hu KQ, Kyulo NL, Esrailian E, Thompson K, Chase R, Hillebrand DJ. Overweight and obesity, hepatic steatosis and progression of chronic hepatitis $\mathrm{C}$ : a retrospective study in a large cohort of patients in the United States. J Hepatol 2004; 40(1):147-54.

22. Solis-Herruzo A, Pérez-Carreras M, Eloy R, Fernández-Vázquez I, Garfia C. Factors associated with the presence of nonalcoholic steatohepatitis in patients with chronic hepatits C. Am J Gastroenterol 2005; 100(5):1091-8.

23. Durante-Mangoni E, Zampino R, MarroneA ,Tripodi MF, Rinaldi L, Restivo L et al. Hepatic steatosis and insulin resistance are associated with serum imbalance of adiponectin/tumour necrosis factor-alpha in chronic hepatitis $\mathrm{C}$ patients. Aliment PharmacolTher 2006; 24 (9):1349-57.

24. Crespo J, Rivero M, Fabrega E, Cayón A, Amado JA, García-UnzetaMTet al. Plasma leptin and TNF-alpha levels in chronic hepatitis C patients and their relationship to hepatic fibrosis. Dig Dis Sci 2002;47 (7):1604-10.

25. Lu JY, Chuang LM, Yang WS, Tai TY, Lai MY, Chen PJ et al. Adiponectin levels among patients with chronic hepatitis B and C infections and in response to IFN-alpha therapy. Liver Int 2005; 25 (4):752-9.

26. Lawrence Serfaty and Jacqueline Capeau. Hepatitis C, Insulin resistance and diabetes: clinical and pathogenic data. Liver international 2009; 29(Suppl 2):13-25.

27. Younossi ZM, McCullough AJ, Ong JP, Barnes DS, Post A, Tavill A. Obesity and non-alcoholic fatty liver disease in chronic hepatitis C. J ClinGastroenterol 2004; 38(8):705-9.

28. Muzzi A, Leandro G, Rubbia-Brandt L, James R, Keiser O, Malinverni R et al. Insulin resistance is associated with liver fibrosis in non diabetic chronic hepatitis C patients. J Hepatol 2005; 42(1):41-6.

29. Grigorescu M, Corina R, Dana C, Grigorescu MD, Serban A, Neculoiu D et al. Metabolic syndrome, insulin resistance and adiponectin level in patients with chronic hepatitis C. J Gastrointestin Liver Dis 2008; 17(2):147-54.

30. D'souza R, Sabin CA, Foster GR. Insulin resistance plays a significant role in liver fibrosis in chronic hepatitis $\mathrm{C}$ and in the response to antiviral therapy. Am J Gastroenterol 2005; 100 (7):1509-15.

31. Rubbia-Brandt L, Fabris P, Paganim S, Leandro G, Male PJ, GiostraEet al. Steatosis affects chronic hepatitis C progression in a genotype specific way Gut 2004; 53 (3): 406-12. 